\title{
Miscanthus as Cellulosic Biomass for Cellulose Acetate Production
}

\author{
Jian Liu*, Chengguo Li, Lihui Gan and Minnan Long \\ College of Energy, Xiamen University, China
}

Submission: June 07, 2017; Published: June 27, 2017

*Corresponding author: Jian Liu, College of Energy, Xiamen University, Xiamen 361102, PR China, Email: jianliu@xmu.edu.cn

Abstract

Miscanthusis a kind of potential feedstock for biomaterials because of the promising high yields of biomass per unit of planted area. This short communication addresses the pretreatment and conversion of Miscanthus biomass for cellulose acetate production. The average cellulose content in dried biomass of Miscanthusis-75.3\%. A number of pretreatment methods have been applied in order to enhance digestibility of Miscanthus biomass for cellulose separation. Pretreatment of Miscanthus biomass using $\mathrm{NaOH} / \mathrm{H} 2 \mathrm{O} 2$ results in a significant release of crystalline state cellulose. As cellulose acetate is produced by reaction of the cellulose from pretreatment, the degree of substitutionis-2.93, meeting the criterion of federal trade commission guidelines. The ferric chloride was chosen the best catalyst in the process.

Keywords: Miscanthus; Cellulose acetate; Degree of substitution; Optimization; Ferric chloride

\section{Introduction}

With the shortage of fossil resources, using biomass as a substitute for fossil resources became a hotspot of study [1,2]. A procedure for synthesizing cellulose acetate with high degree of substitution from Miscanthus biomass was developed and we also choose ferric chloride as a new catalyst to prepare cellulose acetate. The Miscanthus biomass, Miscanthus cellulose and cellulose acetate were characterized by SEM, XRD, FT-IR, TG and DSC.

The optimum conditions for pre treating Miscanthus biomass with $\mathrm{NaOH} / \mathrm{H}_{2} \mathrm{O}_{2}$ were determined. The pretreatment factors (pretreatment temperature, time and number of times) were optimized. The content of cellulose, hemicellulose and lignin for prepared Miscanthus fiber under optimum condition $(70 \mathrm{~h}, 3 \mathrm{~h}$, 3 times) were $75.3 \%, 17.3 \%, 5.1 \%$. The results of SEM, XRD, FTIR, TG and DSC indicated that the method of $\mathrm{NaOH} / \mathrm{H}_{2} \mathrm{O}_{2}$ could effectively remove lignin of Miscanthus biomass without breaking crystal structure of cellulose, which also confirmed former reports $[3,4]$. This method was simple and friendly to environment.

The optimum conditions for preparing cellulose acetate with Miscanthus fiber by reacting with acetic anhydride catalyzed with concentrated sulfuric acid in an acetic acid solvent were determined. The esterification factors (catalyst volume, reaction temperature, reaction time and acetic anhydride volume) were optimized. After optimization $(20 \mu \mathrm{L} / \mathrm{g}, 50 \mathrm{~min}, 60 \mathrm{~min}, 6$ $\mathrm{mL} / \mathrm{g}$ ) the degree of substitution (DS) of 2.8 and the intrinsic viscosity ( $[\eta])$ of $1.24 \mathrm{dL} / \mathrm{g}$ for Miscanthus cellulose acetate were achieved. The degree of substitution met the criteria of cellulose triacetate of the federal trade commission guidelines. The SEM images showed the structure of Miscanthus cellulose was changed from crystalline state to granulate after esterification reaction. The XRD analysis indiacated the crystalline region was broken by esterification reaction. The FT-Reanalysis illustrated the hydrogen atoms were replaced by acetyl on the cellulose molecules. The thermal analysis confirmed Miscanthus cellulose acetate was thermoplastic.

The catalytic effects of new catalysts were determined by titration method. The DS of prepared cellulose acetate catalyzed respectively by ferric chloride, aluminum chloride, zinc chloride, sodium chloride, hydrochloric acid, ferrous sulfate, ferric sulfate, sodium sulfate were $2.95,0.21,0.31,0.11,0.3,2.12,0.29,0.10$. The catalytic effects of ferric chloride were best, it might by relate with the solubility in the acetic acid/acetic anhydride system and electronic absorption effect of the cation. The results show that ferric chloride is suitable for the preparation of cellulose acetate.

The optimum conditions for preparing cellulose acetate with cellulose by reacting with acetic anhydride catalyzed with ferric chloride in an acetic acid solvent were determined. The 
esterification factors (catalyst volume, reaction temperature and reaction time) were optimized. The degree of substitution for prepared cellulose acetate under optimum condition $(0.200 \mathrm{~g} / \mathrm{g}$, $50 \mathrm{~min}, 45 \mathrm{~min}$ ) were 2.93 , which was met the criteria of cellulose triacetate of the federal trade commission guidelines. The SEM images showed the structure of cellulose was changed from sarciniform to granulate after esterification reaction. The XRD analysis indiacated the crystal structure was changed, the peak of cellulose was disappeared. The FT-Reanalysis illustrated the hydrogen atoms were replaced by acetyl on the cellulose molecules. The solution-state NMR showed the connection relation between carbon atom and hydrogen atom as well as chemical shift of groups, which confirmed the sample as cellulose acetate from the molecular structure. In conclusion, ferric chloride could be catalyst for preparing cellulose acetate. Therefore, Miscanthus cellulose could replace expensive cotton fiber for preparing cellulose acetate.

\section{Acknowledgement}

This work was supported by the research fund from the Xiamen Southern Oceanographic Center (No.14GZP59HJ29),
Fujian Provincial Department of Ocean and Fisheries (No.201527), and President Fund of Xiamen University (20720150090).

\section{References}

1. Pereira S, Costa M (2017) Short rotation coppice for bioenergy: From biomass characterization to establishment-A review. Renewable and Sustainable Energy Reviews 74: 1170-1180.

2. Mohapatra S, Mishra C, Sudhansu SB, Hrudayanath T (2017) Application of pretreatment, fermentation and molecular techniques for enhancing bioethanol production from grass biomass-A review, Renewable and Sustainable Energy Reviews 78: 1007-1032.

3. Alvarez-Vasco C, Zhang X (2017) Alkaline hydrogen peroxide (AHP) pretreatment of softwood: Enhanced enzymatic hydrolysability at low peroxide loadings. Biomass and Bioenergy 96: 96-102.

4. Tingzhi L, Huiren H, Zhibin H, Yonghao N (2011) Treatment of poplar alkaline peroxide mechanical pulping (APMP) effluent with Aspergillus niger. Bioresour Technol 102(15): 7361-7365.

\section{Your next submission with Juniper Publishers will reach you the below assets}

- Quality Editorial service

- Swift Peer Review

- Reprints availability

- E-prints Service

- Manuscript Podcast for convenient understanding

- Global attainment for your research

- Manuscript accessibility in different formats ( Pdf, E-pub, Full Text, Audio)

- Unceasing customer service

Track the below URL for one-step submission https://juniperpublishers.com/online-submission.php 